\title{
HABIT AND HETEROGENEITY IN THE YOUTHFUL DEMAND FOR ALCOHOL
}

\author{
Michael J. Moore \\ Philip J. Cook
}

Working Paper No. 5152

\author{
NATIONAL BUREAU OF ECONOMIC RESEARCH \\ 1050 Massachusetts Avenue \\ Cambridge, MA 02138 \\ June 1995
}

Earlier versions of this paper were presented at the Marketing Workshop and at the Center for the Study of Business, Regulation, and Social Policy at Duke University, the Labor/Population Workshop at Yale University, the NBER Health Economics Summer Institute, and the annual meetings of the American Public Health Association. Comments provided by seminar participants, and also by Michael Grossman, John Mullahy, and Jody Sindelar, are gratefully acknowledged. This paper is part of NBER's research program in Health Care. Any opinions expressed are those of the authors and not those of the National Bureau of Economic Research.

(C) 1995 by Michael J. Moore and Philip J. Cook. All rights reserved. Short sections of text, not to exceed two paragraphs, may be quoted without explicit permission provided that full credit, including $\odot$ notice, is given to the source. 


\title{
HABIT AND HETEROGENEITY IN THE YOUTHFUL DEMAND FOR ALCOHOL
}

\begin{abstract}
Observed patterns of youthful drinking indicate substantial persistence. This paper analyzes how much of that persistence reflects the actual development of a habit, and how much is due to unobserved aspects of the individual and the environment. The role of restrictions on alcohol availability, both in the current period and in adolescence, is also explored. We find that much of the observed persistence represents habit formation, and not unobserved characteristics. Consequently, restrictions on availability, particularly at an early age, alter subsequent patterns of alcohol consumption and abuse.
\end{abstract}

Michael J. Moore

Fuqua School of Business

Duke University

Durham, NC 27708

and NBER
Philip J. Cook

Sanford Institute of Public Policy

Duke University

Durham, NC 27708 


\section{Introduction}

Congress established in 1984 a national minimum drinking age of 21 , primarily because of public concern with the acute effects of youthful drinking on traffic safety (Coate and Grossman, 1988; Cook, 1981; Cook and Tauchen, 1984; Males, 1986). This same concern provides support for increases in alcohol excise taxes (Cook and Moore, 1994; Grossman et al., forthcoming). Restrictions on alcohol availability may also have beneficial effects over the longer term. In an earlier paper, we demonstrated that youths who grow up in states with restrictive alcohol policies tend to go farther in school than their socioeconomic twins in more liberal states (Cook and Moore, 1993). Here we analyze the extent to which youthful drinking is habit forming, and in particular, whether the availability of alcohol to youths has some influence on how much they drink later in life.

That drinking can be habit forming is hardly in doubt. But the strength of this effect - the "addictivity" of alcohol --has not been adequately assessed for youthful populations Certainly there is much evidence demonstrating persistence in drinking over the life course. But assigning the proper causal interpretation to this pattern is not so easy.

Data from the National Longitudinal Survey of Youth provide information on drinking by a large cohort of youths for the years 1982-85 and 1988-89. In our cross-section regression analysis of the 1984 data on younger and older cohorts of the sample, and in a sample that pools youths of all ages over the years 1983-1985, lagged drinking is strongly predictive of current drinking, even after controlling for a wide array of individual attributes, prices, and legal drinking status. This pattern is consistent with a habit formation process, but also with two other causal processes that have quite different implications for policy.

First, if there exists unobserved heterogeneity in tastes, lagged drinking acts as a proxy 
for these tastes, and the observed association between lagged and current drinking exaggerates the habit formation effect. Second, unobserved "wetness" of the individual's environment, if it tends to persist, will also give rise to a spurious association between current and past drinking. For example, youths who come from a heavy-drinking family may begin drinking young and stay with it as long as they are under the influence of family members. If family drinking is not accounted for, this pattern is indistinguishable from habit formation.

Most likely, the observed persistence in drinking results from all three influences: habit, environment and tastes. But since habit formation has different implications than the explanations based on heterogeneity, we seek to distinguish among them in our estimates. For this purpose, we utilize two estimation strategies: instrumental variables, and the use of early environmental determinants of drinking in " "reduced form" specification.

In the instrumental variable (IV) estimates, we pool observations for the years 198385, and estimate habit formation equations in which drinking is a function of age, period, contemporaneous price and legal drinking status, and other features of the individual's circumstances, together with drinking during the previous year. We also estimate a version of this model that includes drinking in the subsequent year, as suggested by the "rational addiction" literature (Becker and Murphy, 1988; Becker, Grossman, and Murphy, 1994), in which individual's current drinking decisions are influenced by the anticipated future costs of acquiring a "habit." As excluded instruments we use one-period lags and leads of the time-

\footnotetext{
'A recent effort that parallels ours (but differs with respect to nature of the data and estimation strategy) is by Grossman, Chaloupka, and Sirtalan (1994). They use Monitoring the Future data, including ten cohorts of high school seniors who are surveyed every two years after graduation. Their focus is on developing evidence on forward-looking behavior in the rational addiction framework. The results provide some support for this possibility.
} 
varying exogenous variables, together with the early environment variables, yielding estimated habit effects that should be free from heterogeneity bias. A positive coefficient on the lagged drinking variable suggests that youthful drinking is habit forming, and a similar result on the future drinking variable indicates forward-looking ("rational") behavior. The typical result across a variety of specifications is that the IV estimate of the habit effect is about threefourths as large as the OLS estimate, and remains significantly positive. This result holds in both the forward-looking and "myopic" models.

The alternative econometric approach is to estimate a drinking demand equation for adults that includes measures of alcohol availability that characterized their teen years. If the early availability variables significantly affect current drinking, habit formation is indicated.

Our results suggest that the early drinking environment is indeed an important determinant of heavy drinking by young adults. Both males and females who live in high purchase age states at age 14 "binge" drink less in their early twenties than do those youths who grew up in less restricted settings. Other measures of alcohol consumption are also sensitive to early environment, particularly for women.

Thus there appears to be a strong habitual component in youthful drinking. Youthful drinking causes drinking in later years, and restricted access to alcohol among early teens reduces drinking in their early twenties. Our results indicate that the regulation of availability of alcohol to youths has sobering effects, both immediately and in the long run.

Throughout the paper, we will adopt the convention of referring to both structural models as habit formation models, distinguishing them according to whether they assume myopic of forward-looking behavior. 


\section{Empirical Framework}

In the empirical analysis, we will examine three models of the demand for alcohol. The first is a myopic habit formation model, where cumulative past consumption creates a "stock" of habit that influences current consumption." In the habit formation model an individual who has consumed a large quantity of alcohol in the past will derive less utility from any current consumption level than would be derived, had previous consumption been lower. 4

An undesirable feature of the habit formation model as developed in the literature is that, although it recognizes the dependence of current consumption on past consumption, it assumes myopic behavior, in that the consumer does not take into account the dependence of future tastes on current consumption. The rational addiction model rectifies this omission by casting habit forming behavior in an intertemporal framework. Our second empirical model permits the rational addiction hypothesis to be tested. Our results are consistent with the Becker - Grossman - Murphy formulation.

The third demand model that we estimate is the "reduced form" version of the habit formation model, where past (and future) consumption are replaced by variables that act as proxies for the availability of alcohol in the youth's early environment. ${ }^{5}$ As shown by Chamberlain (1984), this model allows us to test for the presence of habit formation in a

\footnotetext{
${ }^{3}$ See, for example, Pollack (1970, 1976), Phlips (1972), Phlips and Spinnawyn (1982), Alessi and Kapetyn (1991), and Heien and Durham (1991).

For estimates of a standard neoclassical demand model that ignores addiction effects, see Cook and Moore (1994).

'This model is not, strictly speaking, a true reduced form. Rather, we eliminate potentially endogenous right hand side drinking variables by substituting measures of the early drinking environment.
} 
straightforward manner.

The economics literature offers a number of analogous inquires, where the econometric challenge is to distinguish between state dependence and heterogeneity (Heckman, 1981a,b,c). An individual who was unemployed last period is relatively more likely to be unemployed this period. Does past unemployment therefore "cause" future unemployment, or does unemployment in each period simply act as a proxy for some unobserved traits that render the individual more prone to unemployment (Ellwood, 1982)? Labor force participation patterns of married women (Heckman and Willis, 1977), and a wide range of other behaviors that are strongly autocorrelated give rise to the same question of interpretation. If the event experienced in time $t-1$ somehow alters preferences or opportunities so that the likelihood of experiencing the event in period $t$ is altered, the observed correlation reflects a structural relationship, or "true" state dependence (Heckman, 1981a). ${ }^{6}$ If the event is more likely to be experienced by a given individual only because he or she possesses some permanent trait or characteristic that renders the event more likely, such as unobserved tastes, abilities, or motivation, "spurious" state dependence results, and the observed correlation of events has no structural interpretation. It is also possible that serial correlation in other unobservables will give rise to spurious state dependence. Our reduced form model is not subject to this problem (Hsiao, 1986).

We seek to determine whether the association between current drinking and past drinking reflects the addictive properties of alcohol (true state dependence), or the influences

\footnotetext{
${ }^{6}$ There is sometimes a distinction made in the literature between habit formation and state dependence, whereby habit formation relates to persistence in continuous outcomes (quantities), while state dependence describes persistence in discrete outcomes. We will use the concepts interchangeably as descriptions of the same phenomenon.
} 
of unobserved components of individual tastes (spurious state dependence, or heterogeneity). This distinction is illuminated by specifying a conceptual experiment. Suppose a group of youths are randomly assigned to either a control group or a treatment group. The experimentals are frequently offered drinks, while the controls are somehow kept in a dry environment. The outcomes of this experiment would be measured by the quantity and patterns of alcohol consumption following release from the experimental condition. If the experimentals drink more, we could then conclude that drinking history has a direct effect on current drinking choices. But with non-experimental data, such a conclusion is far more tenuous.

\section{Data}

A simple test of habit formation is based on an analysis of "runs" patterns in youthful drinking. We know whether the NLSY respondents drank in the 30-day period before the interview for each year from 1982 to 1985 . A simple heterogeneity model of this process is the following: Each individual is characterized by some probability, $\mathbf{P}_{\mathrm{i}}$, of drinking in a 30 day period. If drinking decisions from one year to the next are independent, one implication is that permutation sequences, such as $1,0,1,1$ and $1,1,0,1$, should have the same probability, $\mathbf{P}_{\mathrm{i}}^{3}\left[1-\mathbf{P}_{\mathrm{i}}\right]$.

Figure 1 depicts the drinking process in our sample for a discrete outcome -- the decision to drink (prevalence), over the years 1982-85. Persistence is illustrated strikingly in Figure 1. The probability of drinking in 1985 , given three successive years of drinking, equals 0.90 , and that of abstaining, given three previous periods of abstinence, equals 0.84 . 
Clearly, permutations do not have the same likelihood. The probability of three " $1 \mathrm{~s}$ " and a "0" differs from 3\% (for 1101) to 6\% (for 0111). Similar differences are observed for other patterns. It is also clear that past drinking contains information relevant to predicting current drinking, and that more recent information is more important. A simple model fitting the data in Figure 1, where $d_{i=1}=1$ indicates drinking, is

$$
\operatorname{Prob}\left[d_{i, 85}=1\right]=0.16+0.36 d_{i, 84}+0.23 d_{i, 83}+0.16 d_{i, 82}
$$

Of course, this model ignores differences in the individuals. If a similar declining coefficient pattern were observed conditional on these characteristics, however, some form of habit persistence would be indicated.

The empirical analysis is structured around the following maintained hypotheses. We assume that the unobservable determinants of alcohol demand, $\varepsilon_{\mathrm{it}}$ consist of a fixed individual specific taste component, $\alpha_{i}$, and other unobservables that vary over individuals and time, $v_{\text {it }}$

$$
\text { (1) } \varepsilon_{\mathrm{in}}=\alpha_{\mathrm{i}}+v_{\mathrm{it}} \text {. }
$$

The dependent variable will be some indicator of alcohol consumption, such as monthly consumption of drinks, or a binary measure of whether the individual drank, or drank heavily,

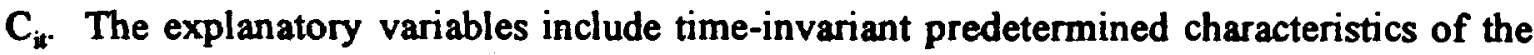
individual, $Z_{i}$, time-varying characteristics representing choices, $X_{i t}$, the availability variables, $\mathbf{P}_{i k}$ and, in the reduced form model, the availability of alcohol in the early years, $\mathbf{P}_{\text {io }}$.

We assume throughout that the individual-specific component is independent of the availability variables and the predetermined characteristics,

$$
E\left[\alpha_{i} \mid Z_{i}, P_{i 0}, P_{i k}\right]=0
$$


and that it is potentially correlated with the $X_{i t}$ and with lagged consumption, $C_{i, t-1}$,

$$
E\left[\alpha_{i} \mid X_{i b} C_{i t-1}, Z_{i}, P_{i 0}, P_{i t}\right] \neq 0
$$

In the forward-looking habit formation models, we add future consumption as a potentially endogenous conditioning variable,

$$
E\left[\alpha_{i} \mid X_{i t}, C_{i t+1}, C_{i t l-1}, Z_{i}, P_{i 0}, P_{i n}\right] \neq 0
$$

\section{The Standard Demand Model}

In the standard demand framework, individual $i$ is assumed to maximize a utility function of the form

$$
\mathrm{U}_{\mathrm{it}}=\mathrm{U}\left(\mathrm{C}_{\mathrm{it}}, \mathbf{Y}_{\mathrm{it}} ; \mathbf{X}_{\mathrm{it}}, \mathbf{Z}_{\mathrm{i}}\right)
$$

subject to a single-period budget constraint

$$
P_{i}^{\prime} C_{i i}+Y_{i n}=A_{i}
$$

where $P_{i k}^{\prime}$ denotes the price of the alcohol consumption good, $Y_{i k}$ all other goods (whose price is normalized) and $\mathbf{A}_{\mathrm{i}}$ individual wealth.' A common approach to deriving the empirical demand equation is to assume that utility is quadratic in $C$ and $Y$ and that the marginal utility of wealth is constant, which yields the demand function

$$
C_{i \mathrm{i}}=\beta_{0}+\beta_{1} P_{i \mathrm{i}}+\beta_{2} Z_{i}+\beta_{3} X_{i \mathrm{i}}+\beta_{4} A_{i}+\varepsilon_{i \mathrm{i}}
$$

We are interested primarily here in estimating the coefficient vector $\beta_{1}$, which also includes the effects of other availability variables, such as legal drinking status. The individual effect, if correlated with the $X_{i,}$, will impart bias to estimates of this coefficient, and to all of the others. One strategy to alleviate this problem is to drop the contaminated variables (the $\mathrm{X}_{\mathrm{in}}$ )

\footnotetext{
T In our notation, $P_{\text {it }}^{\prime}$ represents the price, and $P_{i t}$ a vector of availability variables including $P_{i t}^{\prime}$.
} 
and estimate a "short form" version of the model that contains only exogenous variables on the right hand side

$$
C_{i t}=\beta_{0}+\beta_{1} P_{i t}+\beta_{2} Z_{i}+\varepsilon_{i t}
$$

We present estimates of both short and long form models below.

\section{Habit Formation}

Habit formation models assume some dependence of current utility on past consumption. They are distinguished according to whether they also assume myopia (the traditional habit formulation) or not (the rational addiction model). In one version of the myopic habit model, the utility of person $\mathrm{i}$ depends on both current and the most recent consumption of the habit forming commodity, and on $Y_{\text {it }}$

$$
\mathrm{U}_{\mathrm{it}}=\mathrm{U}\left(\mathrm{C}_{\mathrm{it}} \mathrm{C}_{\mathrm{inh}, \mathrm{l}}, \mathrm{Y}_{\mathrm{in}} ; \mathrm{X}_{\mathrm{it}}, \mathrm{Z}_{\mathrm{i}}\right) \text {. }
$$

Quadratic utility, constant marginal utility of wealth, full depreciation of the addictive stock, and a single period budget constraint yield an empirical habit formation model of the form

$$
C_{i k}=\beta_{0}+\beta_{1} P_{i t}+\beta_{2} Z_{i t}+\beta_{3} X_{i t}+\beta_{4} A_{i}+\beta_{5} C_{i k-1}+\varepsilon_{i x}
$$

The presence of the term $\alpha_{i}$ in equation (1) creates a dependence between the lagged consumption term and the error in equation (4). A least squares estimate of $\beta_{5}$ would reflect both the structural effects of past consumption on current consumption, and the effects of the unobserved heterogeneity. It is not possible, furthermore, to determine the relative importance of the two competing effects using a single cross section of data.

We consider three approaches to handling this problem. Since the data that we use are longitudinal, it is possible to estimate fixed effect versions of equations (2)-(4), so that the individual effect is swept out in the estimation. However, when the model contains a lagged 
dependent variable, as in equation (4), the coefficient estimates will be biased and inconsistent (Nickell, 1981). As shown by Nickell, this bias diminishes as the length of the panel increases. With only three waves of data available, however, we expect the fixed effect estimates to exhibit a considerable negative bias in the estimated habit effect. In addition to this problem, fixed effect estimation of equation (4) gives rise to the problem of specifying the initial conditions (Heckman, 1986). Typically, these conditions are assumed to be exogenous, or the process is assumed to be in equilibrium. Exogeneity cannot be assumed here, because we do not observe the process from its inception, and period-to-period equilibrium in the presence of time varying determinants (the $X_{i t}$ ) is implausible.

An alternative to fixed effect estimation is instrumental variables, if we can find adequate instruments for $C_{i,-1 .}$. Plausible candidates include lagged values of the availability variables, $\mathbf{P}_{\mathrm{it}-1}$, including beer tax rates and minimum age restrictions. Unfortunately, lagged beer taxes are highly collinear with their current values, so that they will add little towards identification of the effect of the lagged consumption term. The past minimum drinking age, on the other hand, is less collinear with the current drinking age, since it changed in a number of states over the sample period. More importantly, many of the youths crossed the purchase age threshold, so that the variable "legal drinking status" provides adequate variability over time. Also, there is no need to limit the analysis to availability measures from the preceding year's environment, as the NLSY data provide information on the youth's state of residence at

\footnotetext{
In this case the bias will not arise due to the individual heterogeneity, but rather due to dependence between the groups means of $\mathrm{C}_{\mathrm{i}, 1 \cdot 1}$ and the error term.
} 
age 14, an age when many youths have begun to experiment with drinking.'

An alternative source of instruments for previous consumption is the lagged $\mathbf{X}_{\mathrm{k}}$, including marital status, living arrangement, and years of schooling. These are sufficiently different from their current values to identify the effect of lagged consumption. They are not necessarily independent of the individual-specific unobservable effect.

Our second approach to testing for state dependence substitutes measures of previous availability for $C_{i t-1}$ directly in equation (4), and estimates a "reduced form" of the model. Significant effects on these variables provide evidence that alcohol consumption has an addictive component. If availability at age 14 affects drinking at age 20 (even after controlling for availability at age 20 ), the most plausible interpretation is that youthful drinking is habit forming. Note that this formulation allows us to distinguish between the effects of serial correlation and true state dependence (Chamberlain, 1984). ${ }^{10}$ The reduced form model is

$$
C_{i t}=\beta_{0}+\beta_{1} P_{i t}+\beta_{2} Z_{i}+\beta_{3} X_{i t}+\beta_{4} A_{i}+\beta_{6} P_{i 0}+\varepsilon_{i t}
$$

In implementing the reduced form model, we use as our indicator of early availability the minimum purchase age in the individual's state of residence at age 14 . In the language of the

\footnotetext{
'We could also estimate the fixed effect model using instrumental variables. The initial condition problem would remain, however. Since the same solution (instrumental variables) to the heterogeneity problem applies to the untransformed data while the initial condition problem does not, we choose not to utilize the fixed effect approach. Also, any measurement error problems will be magnified in the fixed effect estimation.

${ }^{10}$ Chamberlain points out that the key difference between models with state dependence and those with serial correlation due to unmeasured heterogeneity is whether there exists a dynamic response to an exogenous intervention, i.e., whether $X_{\text {ir }}$ affects $C_{i p} t^{\prime}<t$. If state dependence exists, past values of $X$ will affect $C_{i}$ through the distributed lag response to the change in $X$. If there is no state dependence, the full effect of $X_{\text {w }}$ will be felt in period $t^{\prime}$. Thus, a test for state-dependence that does not depend on controls for unmeasured heterogeneity and serial correlation is whether $E\left[C_{i t} \mid X_{i p}, X_{i r}, Z_{i j}\right]=E\left[C_{i d} \mid X_{i p} Z_{i j}\right]$. If these expectations are not equal, we can be confident that state dependence exists.
} 
controlled experiment, we are treating the minimum purchase age at age 14 as the randomly assigned treatment. We hypothesize that, if alcohol has addictive properties, individuals who received a high purchase age "treatment" will drink less now than those otherwise identical individuals who grew up in a "wetter" environment.

\section{Rational Addiction}

In the rational addiction model, past consumption affects current utility, current consumption affects future utility, and the consumer takes both into account in choosing $\mathbf{C}_{\mathrm{it}}$. Lifetime utility is

$$
V_{i n}=\sum_{i \infty}^{\infty} \beta U_{i t}
$$

where $\beta$ is a subjective discount factor. Combined with a lifetime budget constraint, and assuming quadratic utility, constant marginal utility of wealth, and a $100 \%$ depreciation rate for the addictive stock (see Becker, Grossman, and Murphy (1994) for details), the rational addiction model yields the empirical model

$$
C_{i t}=\beta_{0}+\beta_{1} P_{i t}+\beta_{2} Z_{i}+\beta_{3} X_{i t}+\beta_{4} A_{i}+\beta_{5} C_{i t-1}+\beta_{7} C_{i, t+1}+\varepsilon_{i t}
$$

Becker, Grossman, and Murphy suggest the following empirical strategy for estimating equation (6). The model implies that period $t$ consumption is independent of prices in periods $t-1$ and $t+1$, given consumption in those periods. Thus, lagged and future prices can act as instruments for lagged and future consumption, which are endogenous due to the presence of the individual-specific effect in the error term. Becker, Grossman, and Murphy, and elsewhere Chaloupka (1991), estimate this model for tobacco consumption, and find results that support the theory of rationally addictive behavior. Grossman et al. (1994) estimate the 
model using data on alcohol consumption from the Monitoring the Future Surveys (Johnston and O'Malley, 1988, 1992).

One appealing aspect of the approach taken here is the presence of a future variable, legal drinking status, that is well known by youths in advance. Becker, Grossman, and Murphy note that the use of future prices as instruments will impart downward bias to the estimated coefficient on $\mathrm{C}_{\mathrm{i} t+1}$ if the instrument is measured with error. Since future prices and taxes are not known with certainty, measurement error seems likely, and Becker, Grossman, and Murphy's statistical tests bear this out."

We thus have three models with which to test the importance of addiction: the myopic habit formation model of equation (4), the forward-looking habit formation model given by equation (6), and the reduced form model of equation (5).

\section{Sample Characteristics}

Data for this study are drawn from the National Longitudinal Survey of Youth, a panel of 12,686 youths aged $14-21$ in 1979 , that has been conducted annually since 1979 . In addition to extensive information on the sample youth's labor market experiences, education, family composition, and personal characteristics, the NLSY asked a series of questions related to drinking behavior in the years 1982-85, 1988, and 1989. We focus on the earlier years here, with an analysis of the later drinking to be taken up in future work. The pooled sample

\footnotetext{
"The value of legal drinking status as an instrument for future consumption is limited to the extent that youths in 1983 and 1984 have not crossed the legal threshold.
} 
uses information on drinking and other variables from the $1982-85$ waves of the panel. ${ }^{12}$ The data are combined with data on beer taxes and minimum purchase ages from various sources.

Table 1 presents the principal descriptive characteristics of the data for the 1983 wave of the panel, broken down by gender, and defines the variables. The sample is divided more or less evenly between males and females. The real beer tax per 12 ounce can equals about 2 cents, and 83 percent of the sample members have passed the legal minimum drinking age by 1983. The variables that we assume to be independent of the individual heterogeneity (the $Z_{i}$ ) include all the predetermined time-invariant determinants of drinking. These include family human capital variables indicating the extent of parent's education, race indicators, and indicators of parental drinking, primary ethnic origin, and the religion in which the youth was raised. We also include a full set of age and year dummy interaction variables in all estimated equations. The distribution of the sample members across all of these categories is summarized in Table 1.

As Table 1 indicates, males and females differ substantially in terms of their alcohol consumption. Males consume an average of 32 drinks containing alcohol every $\mathbf{3 0}$ days, with the figure for females less than half that. About 85 percent of males had at least one drink in the last month, as compared to 75 percent of the females. Binge drinking, which we define as at least 4 occasions of 6 or more drinks in the last month, is three times more prevalent among males.

The "long form" determinants of individual alcohol consumption include the youth's living arrangement, highest year of schooling completed, body weight, marital status, and an

\footnotetext{
${ }^{12}$ For a detailed description of the construction of the alcobol consumption variables and a descriptive summary of their characteristics, see Cook, Moore, and Pacula (1993).
} 
indicator of whether the individual is in a branch of the armed services. We also experimented with variables measuring the extent to which the youth felt "in control" of his or her life, but these had no explanatory power and are not included in the regressions reported here. ${ }^{13}$ The typical male sample member has completed 12 years of schooling and weighs about 170 pounds. Thirty-three percent live with at least one parent, forty-six percent by themselves, 5 percent in a dormitory, and the remainder live with someone else. Twenty two percent of the males are married.

\section{Empirical Results}

The results to be discussed below are distinguished as follows. In some specifications, two subsamples of the 1983-85 panel are analyzed separately, a "younger cohort," which includes those youths less than 21 years old in 1983, and an "older cohort," which includes all youths at least 24 years old in 1983. Each equation is estimated in "short" and "long" form, with the short form variables restricted to those that we have good reason to believe are exogenous. The long form variables, are potentially endogenous with respect to drinking, since they reflect choices and, as such, are jointly determined with drinking.

As in all demand studies using microdata, the treatment of corner solutions (in this case, observations of zero drinking) presents a problem. We first utilize the two-part approach of Manning et al. (1987), which estimates a participation equation and a log quantity

\footnotetext{
${ }^{13}$ In Cook and Moore (1993) we examine the relationship between drinking and schooling, which is in a sense the opposite relationship posited here. However, in that paper, the primary measure of schooling is eventual graduation or highest grade completed by 1988, while the drinking variable is measured in 1983-84. Thus, the temporal relationship between the drinking and schooling variables differs in that paper and in the specification considered here. But we admit the possibility that schooling, like several other variables in the long form, is quite possibly endogenous.
} 
equation separately, and derive elasticity estimates from the combined equations. Tobit estimates of demand equations are also provided for the reduced form and habit models. In estimating the tobit models, we assume that actual drinking, rather than expected, governs the habit formation process, so that observations of zero drinking should be treated as such, rather than as threshold values when drinking appears as an explanatory variable. Thus, a simultaneous equation tobit model is not called for. However, in testing for exogeneity of the past and future drinking, two-stage Tobit estimates are used. We also estimated each equation using Heckman's selectivity correction, but found the results inferior to those from the twopart and tobit estimation. This conforms with Manning et al.'s Monte Carlo results, which show that the two-part estimator works better than the selectivity correction in the absence of exclusion restrictions on the demand equation and when the dependent variable is highly skewed.

Tables 2 and 3 present estimates of short and long form drinking equations for the males in the younger cohort. These equations do not incorporate addiction in any form, but are useful to establish a basis for evaluating subsequent models. ${ }^{14}$ In particular, they illustrate the sensitivity of dimensions of current alcohol consumption to current tax and legal drinking status, which has been until recently the focus of the literature. The results also illustrate the robustness of the estimates to inclusion of the long form variables, which are potentially endogenous. Finally, the demand equations can be interpreted as reduced forms of a model with no addiction.

Each table presents estimates of three equations. The dependent variables are, first,

\footnotetext{
${ }^{14}$ See also the results in Grossman, Coate, and Arluck (1987), Coate and Grossman (1988), Laixuthai and Chaloupka (1993), and Grossman, Chaloupka, and Sirtalan (1994).
} 
the $\log$ of drinks per month, conditional on some drinking having occurred, second, a binary indicator of whether the youth had anything to drink in the past 30 days, and third, a binary indicator of "binge drinking," which we define as at least 4 episodes of 6 or more drinks in the past month. The latter two equations are estimated as logits, so that the coefficients give the effect of variation in the explanatory variable on the log-odds of the outcome.

The results in Table 2 can be summarized as follows: Beer tax increases significantly reduce consumption by drinkers, and decrease the likelihood of drinking and of binge drinking, although the latter two effects are not significant at the 0.05 confidence level. Legal drinking status in 1984 appears to be weakly positively related to the drinking behaviors. Youths who report an alcoholic father are significantly more likely to drink, and to drink heavily. Parental education does not exhibit any systematic influence on youths in this particular age/sex group, nor does family size. In results not shown, certain ethnic backgrounds (British, Irish, German, American Indian) drink more than average, while others (Oriental) drink less. Finally, conditional on all the other regressors, religious background had no discernible effect on drinking patterns.

In the Table 3 results, which reflect the addition of the long form variables, the beer tax effects appear somewhat stronger in terms of statistical significance in the $\operatorname{Pr}(\operatorname{Binge})$ equation, and the legal drinking status variable continues to have only a weak effect. Note that including the long form variables has little effect on the estimated coefficients of the availability variables. Addition of the long form variables eliminates much of the effect of paternal drinking, with the exception of the participation equation. In terms of their own effects, the long form variables perform reasonably well. Youths who live by themselves are 
more likely to drink, and drink more, than those who live with someone else. Those living in a dorm are also significantly more likely to drink, and somewhat more likely to binge drink. Being married exerts a significant negative effect on all three dimensions of alcohol consumption. Young males who are more highly educated and those who are married drink less, less often, and have fewer binge episodes than their less educated, single counterparts. Finally, heavier young males drink more, and are somewhat more likely to binge drink.

Table 4 summarizes the effects of the availability variables on the three drinking outcomes for a variety of subsamples. The results suggest a consistently strong effect for beer taxes. At the average tax rate of about 0.50 , the coefficient estimates imply a tax elasticity equal to about 0.15 , i.e., a $100 \%$ increase in the beer tax yields a $15 \%$ decrease in quantity demanded. ${ }^{15}$ Legal drinking status, which is only relevant in the young cohort regressions, affects quantity decisions in the pooled male-female sample. The participation logits yield similar results, whereby beer taxes reduce the likelihood of any drinking for females and in the combined sample, while legal drinking status has no significant effect. Binge drinking falls when taxes rise, although the effect is insignificant more often than not. The consistent negative pattern is, nonetheless, suggestive. The legal minimum does not appear to affect binge drinking in this cross section.

\footnotetext{
is To compute the effect of a tax change from the two-part estimates, we use coefficients from the conditional demand equation and the prevalence equation. The effect of a change in the tax rate, dt, on expected drinking, $P D$, then equals $\frac{d P D}{d t}=D \frac{\partial P}{\partial t}+P \frac{\partial D}{\partial t}$. Using the long form results for young males, for example, the effect equals -10.37 for $D=32, P=.85$. The elasticity then equals $-10.37 \frac{t}{P D}$, or about $15 \%$.
} 


\section{Habit Formation Equations}

Although interesting in their own right, the standard demand models do not shed any light on habituation issues. Two questions are of interest here. First, does youthful drinking exhibit habituation in the myopic and/or forward-looking models and, second, what effects do interventions that limit availability have on alcohol consumption?

In answering both questions, it is important to control for individual heterogeneity.

We do this in two ways. Reduced form estimates of the sort suggested by Chamberlain $(1978,1984)$ allow us to identify habituation effects independent of unobserved heterogeneity of a very general form. Instrumental variable tobit estimates of structural myopic and forward-looking habit formation models allow us to describe the habituation process more fully. Both sets of estimates can be used to answer the policy question.

To resolve the heterogeneity issue for the case of youthful alcohol consumption, we estimated three sets of equations, using pooled NLSY data for the years 1982-85. The first are estimates of habit formation models, in both long and short form, which are simply the demand models with a lagged consumption term added. We use both drinks per month in a tobit framework, which includes zero drinking observations, and the natural log of drinks per month, which does not. ${ }^{16}$ Individuals who abstained from drinking in all four years (1982-85) are dropped from the sample.

Our second set of estimates uses instrumental variables to attempt to remove the heterogeneity from the past and future consumption terms. Our selection of instruments is guided by the structure of the demand equations. In both short and long forms, we use lags

\footnotetext{
${ }^{16}$ As noted earlier, the semilog equation estimates can be combined with prevalence equation estimates such as those found in Tables 2 and 3 to compute elasticities as shown by Manning et al. (1987).
} 
and leads of all the time-varying exogenous variables as instruments for lagged and future consumption. To the extent that the long form variables, such as education, marital status, and living arrangement, are not independent of the individual heterogeneity, their use as instruments is questionable. Note, however, that the earlier results were not sensitive to this aspect of model specification. The beer tax and legal drinking status variables are clearly valid instruments, but the adjacent beer taxes will be plagued by collinearity with the contemporaneous beer tax. We also use as instruments minimum purchase age dummies based upon the sample member's state of residence at age 14. Note also that, for purposes of testing the rationality hypothesis, the standard errors of the two-stage tobit do not require correction (Pagan, 1984).

Our third empirical approach estimates both short and long form reduced form equations, where the lagged consumption variable is eliminated by substituting a subset of the instrumental variables as regressors. Of particular interest are the purchase age at age 14 dummy variables, as the coefficients on these variables will tell us whether the youth's early environment affects later drinking. These variables are not related to the individual heterogeneity in tastes. Estimates of their effects also provide evidence on whether alcohol possesses any addictive properties. ${ }^{17}$

\section{Reduced Form Estimates}

Tables 5 and 6 present the estimates of the reduced form habit equations, where the right-hand side consumption variables have been replaced by indicators of the wetness of the

\footnotetext{
${ }^{17}$ The reduced form specification is similar to that in Cook and Moore (1993), where beer taxes and minimum purchase age in 1983 were used as regressors in reduced form equations for college completion and years of schooling completed by 1988.
} 
youth's early environment: two dummy variables indicating the minimum purchase age in the respondent's state of residence at age 14 . If the early environment matters, we would expect a positive coefficient on the purchase age dummies, as the excluded category denotes an MPA of 21 at age $14 .^{18}$

The results in Table 5 are quite strong for females, but drinking by males does not appear to be significantly affected by early environment. Legal status matters for both males and females. In both the long and short form equations, regardless of the form of the dependent variable, females who grow up in an environment that restricts drinking consume less alcohol when they are older than otherwise similar females who grew up in a more restrictive environment. Finally, increases in beer taxes significantly reduce drinking. In the drinks per month equations, which include observations of zero drinking, the tax effect is not significant for males.

Table 6 presents estimates of reduced form equations describing the decisions to drink (the participation equation) and to drink heavily (the binge drinking equation). In the participation equation, a significant negative effect of the beer tax is indicated for males and females in both the long and short form equations. Current legal status does not affect the decision to drink, but the early drinking environment appears to affect the participation rates of females.

The most interesting results in Table 6 are found in the binge drinking equation. Remember that, in the reduced form model, the coefficients on the early environment

\footnotetext{
1"We also experimented with an additional early environment variable that measured state level per capita alcohol consumption in respondent's state at age 14. The variable performed well for females, but not for males, yielding wrong-signed and significant effects. Furthermore, inclusion of this variable did alter the results on the other variables.
} 
variables indicate whether the behavior in question is addictive, altering one's preferences towards heavier consumption. Conceptually, we would most likely expect to find such an effect in a heavy drinking equation. ${ }^{19}$ This is, in fact, what we find. Heavy drinking has a strong state-dependent component, as evidenced by the significant effect of an 18 year old minimum purchase age on binge drinking by both males and females. The 19-20 year dummy is not significantly different from the excluded 21 year old category. Beer taxes exhibit a consistent downward effect on participation, while the other availability effects are weaker.

\section{Rational Addiction Estimates}

The reduced form approach represents the most robust evidence that drinking alters preferences. Given this, a structural analysis (with suitable controls for heterogeneity) will provide more insight into the nature of the process.

We consider two models, one of which (the habit formation model) is a special case of the other (the rational addiction model). The latter model is more sensible, in that it does not assume myopic behavior. The myopic model is more fully developed in the literature, and is still of some interest as a special case.

Table 7 presents tobit estimates of the myopic and forward-looking habit formation models. Results are presented for males and females separately, and combined. Only minor differences appear when comparing coefficient estimates by gender, so we will focus on the results for the combined sample. Furthermore, results of Hausman - Wu tests of exogeneity indicate that, for the most part, the OLS estimates are acceptable. In one case, the long form

\footnotetext{
${ }^{19}$ See Grossman et al. (1994) for a detailed discussion of this point.
} 
rational addiction estimates indicate that the 2 SLS estimates are more appropriate. Partial $\mathbf{R}^{2}$ tests of the significance of the excluded instruments are consistently satisfactory in the combined sample results (Bound, et al., 1994). Note also that the poor performance of the 2SLS estimates in the male subsample appears to be due to poor quality of identifying instruments, which add no explanatory power.

The combined sample OLS results provide strong evidence that drinking is addictive, as evidenced by the significant coefficients on lagged consumption. Rationality in the sense described by Becker, Grossman, and Murphy (1994) is also indicated, as the leading consumption term is significant in both the short and long form estimates. Current availability matters, as evidenced by the beer tax and legal drinking status variables.

Evidence on the heterogeneity issue is mixed. In two of four cases, the two-stage estimate of the addiction coefficient is smaller than its OLS counterpart. More generally, however, habit appears to be the dominant force underlying the observed persistence. With the exception of the short form rational addiction models, the OLS and 2SLS estimates of the habit and rationality effects are very similar in magnitude, as borne out by the Hausman-Wu tests, suggesting that unobserved heterogeneity is not a major influence.

\section{Conclusions}

We sought to examine the demand for alcohol by youths, focusing on two distinct questions. First, in the standard demand framework, do restrictions on alcohol availability reduce consumption, and the likelihoods of drinking and getting drunk? Second, in habit formation and addiction models, can we decompose the observed association between drinking in the current period and adjacent periods into true "structural" habit effects, and 
those effects that reflect unobserved heterogeneity in tastes and environment?

Our results suggest the following: First, availability matters. In the results reported here, beer tax increases lead to reductions in quantity consumed and the likelihood of drinking and, in some cases, in the likelihood of getting drunk. Legal drinking status appears to be effective in controlling drinking by females, less so for males. With respect to the habituation question, both our structural results and our reduced form results suggest a strong role for habit formation in determining the long run demand for alcohol. In particular, youths who drink heavily now are more likely, as a result of that experience, to drink heavily in the future. Similarly, youths exposed to restrictive alcohol policies in their early years will drink less heavily in later years than those who are not. The role of unobserved heterogeneity is at best, weak. 
Alessi, Rob, and Arie Kapetyn (1991), "Habit Formation, Interdependent Preferences, and Demographic Effects in the Almost Ideal Demand System," Economerric Journal 101, 404419.

Becker, Gary S. and Kevin M. Murphy, 1988, "A Theory of Rational Addiction," Joumal of Political Economy 96(4), 675-700.

Becker, Gary S., Michael Grossman, and Kevin M. Murphy, 1994, "An Empirical Analysis of Cigarette Addiction," American Economic Review 84(3), 396-418.

Beer Institute, 1992, Brewers Almanac 1992, Washington DC: The Institute.

Bound, John, David A. Jaeger, and Regina Baker, 1993, "The Care can be Worse that the Disease: A Cautionary Tale Regarding Instrumental Variables," NBER Technical Working Paper No. 137.

Chaloupka, F., 1991, "Rational Addictive Behavior and Cigarette Smoking," Joumal of Political Economy 99(4), 722-742.

Chamberlain, Gary, 1984, "Panel Data," in Handbook of Econometrics, vol.2, Z. Griliches and M. Intriligator, eds., pp. 1247-1318 (Amerstam: North-Holland).

Coate, Douglas and Michael Grossman, 1988, "Effects of Alcoholic Beverage Prices and Legal Drinking Ages on Youth Alcohol Use," Joumal of Law \& Economics 31(1), 145-171.

Cook, Philip J. and George Tauchen, 1984, "The Effect of Minimum Drinking Age Legislation on Youthful Auto Fatalities, 1970-1977," Journal of Legal Studies 13, 169-190.

Cook, Philip J., 1981, "The Effect of Liquor Taxes on Drinking, Cirthosis, and Auto Fatalities," in Moore, Mark H. and Dean R. Gerstein, eds., Alcohol and Public Policy: Beyond the Shadowy of Prohibition, Washington, DC: National Academy Press, 255-285.

Cook, Philip J. and Michael J. Moore, 1993, "Drinking and Schooling." Journal of Health Economics 12, 411-429.

Cook, Philip J. and Michael J. Moore, 1994, "This Tax's for You: The Case for a Higher Beer Tax," National Tax Journal.

Cook, Philip J., Michael J. Moore, and Rosalie Pacula, 1993. "Drinking by Young Adults: Demographics," working paper, Duke University.

Ellwood, David T., 1982, "Teenage Unemployment: Permanent Scars or Temporary Blemishes," in The Youth Labor Market Problem: Its Nature, Causes, and Consequences, National Bureau of Economics Growth, Chicago, Il: University of Chicago Press. 
Grossman, Michael, Frank Chaloupka and Ismail Sirtalan, 1994, "An Empirical Analysis of Alcohol Addiction: Results from the Monitoring the Future Panels, working paper.

Grossman, Michael, Douglas Coate, and Gregory M. Arluck, 1987. "Price Sensitivity of Alcoholic Beverages in the United States," in Holder, Harold D., ed., Control Issues in Alcohol Abuse Prevention: Strategies for States and Communities, Greenwich: JAI Press, Inc., 169-98.

Grossman, Michael, Frank J. Chaloupka, Henry Saffer, and Adit Laixuthai, forthcoming, "Effects of Alcohol Price Policy on Youth: A Summary of Economic Research," Joumal of Research on Adolescence.

Hausman, Jerry A., 1978, "Specification Tests in Econometrics," Econometrica 46 (5), 1251 1271.

Heckman, James J., 1981a, "Heterogeneity and State Dependence," in Studies in Labor Markets, Sherwin Rosen (ed.), Chicago, IL: University of Chicago Press.

Heckman, James J., 1981b, "The Incidental Parameters Problem and the Problem of Initial Conditions in Estimating a Discrete Time-Discrete Data Stochastic Process," in Structural Analysis of Discrete Data with Econometric Applications, Charles F. Manski and Daniel McFadden (eds.), Cambridge, MA: The MIT Press.

Heckman, James J., 1981c, "Statistical Models for Discrete Panel Data," in Structural Analysis of Discrete Data with Econometric Applications, Charles F. Manski and Daniel McFadden (eds.), Cambridge, MA: The MIT Press.

Heckman, James J. and Robert Willis, 1977, "A Beta-logistic Model for the Analysis of Sequential Labor Force Participation of Married Women," Joumal of Political Economy, 85 (1), 27-58

Heien, Dale, and Cathy Durham (1991), "A Test of the Habit Formation Hypothesis Using Household Data, Review of Economics and Statistics 73(2), 189-199.

Hsiao, Cheng, 1986, Analysis of Panel Data, New York, NY: Cambridge University Press.

Johnston, Lloyd D., Patrick M. O'Malley, and Jerald G. Bachman, 1988, Illicit Drug Use, Smoking and Drinking by America's High School Students, College Students, and Young Adults, Washington, DC: U.S. Government Printing Office.

Johnston, Lloyd D., Patrick M. O'Malley, and Jerald G. Bachman, 1992, Smoking, Drinking, and Illicit Drug Use among American Secondary School Students, College Students, and Young Adults, 1975-1991, Vol. 1, Secondary School Students, NIDA.

Laixuthai, Adit and Frank Chaloupka, 1993, "Youth Alcohol Use and Public Policy," Contemporary Policy Issues, October, 70-81. 
Males, Michael A., 1986, "The Minimum Purchase Age for Alcohol and Young-Driver Fatal Crashes: A Long-Term View," The Journal of Legal Studies 15(1), 181-211.

Manning, Willard G., Naihua Duan, and W.H. Rogers, 1987, "Monte Carlo Evidence on the Choice Between Sample Selection and Two-Part Models," Joumal of Econometrics 35, 59-82.

Nickell, Stephen, 1981, "Biases in Dynamic Models with Fixed Effects," Econometrica 49(6), 1417-1426.

Pagan, Adrian, "Issues in the Analysis of Regressions with Generated Regressors," International Economic Review 25(1), 1984, 221-247.

Phlips, Louis (1978), "The Demand for Leisure and Money," Econometrica 46, 1025-1043.

Phlips, Louis and Frans Spinnewyn (1982), "Rationality versus Myopia in Dynamic Demand Systems, " in Advances in Econometrics, vol. 1, 3-33, JAI Press.

Pollak, Robert A. (1970), "Habit Formation and Dynamic Demand Functions," Joumal of Political Economy 78, 745-763.

Theory 13, 272-297.

(1976), "Habit Formation and Long-Run Utility Functions," Journal of Economic 


\section{Figure 1}

Probability Tree for Drinking Prevalence, 1982-85*
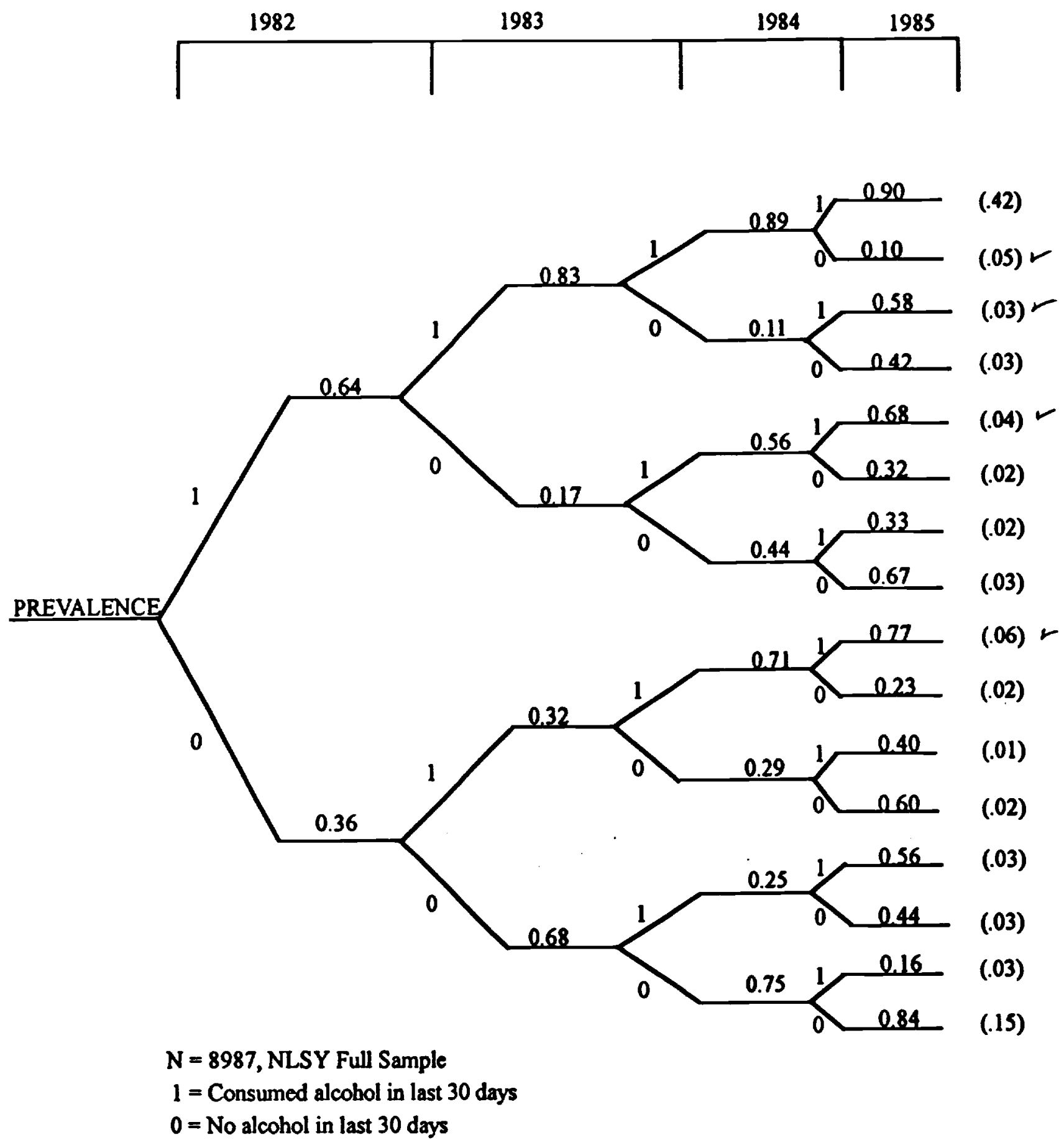

- Figure in parenthesis equals probability of observing complete sequence 
Table 1

\section{Descriptive Statistics and Variable Definitions}

NLSY Sample

$\begin{array}{lccl}\text { Veriable } & \text { Males } & \text { Eemales } & \text { Definition } \\ \text { Beer Tax } & \begin{array}{cc}0.480 \\ (0.531)\end{array} & \begin{array}{c}0.453 \\ (0.498)\end{array} & \begin{array}{l}\text { Tax (in dollars) per 24-12 oz. cans } \\ \text { of beer. (Source: Brewer's Almanac). }\end{array} \\ \text { Legal Drinking Status } & \begin{array}{l}0.852 \\ (0.355)\end{array} & \begin{array}{c}0.913 \\ (0.281)\end{array} & \begin{array}{l}\text { Dummy variable. } 1 \text { if sample } \\ \text { member's age exceeds legal minimum in } \\ \text { his or her state of residence; } 0 \text { otherwise. }\end{array}\end{array}$

Minimum Purchase Age

at Age 14

Eighteen

0.546

(0.498)

0.579

(0.494)

Nineteen or Twenty

0.049

$(0.215)$

0.044

(0.205)

Father with

Drinking Problem

Black

Hispanic

Alcohol Consumption

Drinks Per Month

Drinking Prevalence

Binge Drinking

0.165

(0.371)

0.231

(0.422)

0.219

(0.414)

0.167

(0.373)

0.149

(0.357)

0.235

(0.424)

13.92

(25.54)

(46.26)

0.752

(0.432)

$(0.370)$

0.082

(0.274)
Minimum purchase age in sample member's state of residence at age 14, dummy variables.

d.v.: 1 if sample member reports father was an alcoholic: 0 otherwise (1988 variable)

d.v.

d.v.

Number of drinks containing alcohol consumed in last 30 days

d.v.: I if drank any alcobolic beverages in last 30 days

d.v.: 1 if bad 6+ drinks on at least

4 occasions in las 30 days

Parents' Education

(less than 12 years)

Mother

12-15 years

0.516

(0.500)

0.518

$(0.500)$

$16+$ years

0.081

0.078

(0.269)

d.v.

(0.273)

d.v. 


\begin{tabular}{|c|c|c|c|}
\hline Variables & Males & Eemales & Defrnition \\
\hline \multicolumn{4}{|l|}{ Father } \\
\hline 12.15 years & $\begin{array}{l}0.439 \\
(0.496)\end{array}$ & $\begin{array}{c}0.454 \\
(0.498)\end{array}$ & d.v. \\
\hline $16+$ years & $\begin{array}{l}0.158 \\
(0.365)\end{array}$ & $\begin{array}{c}0.155 \\
(0.362)\end{array}$ & d.v. \\
\hline Number of Siblings & $\begin{array}{l}3.701 \\
(2.573)\end{array}$ & $\begin{array}{c}3.700 \\
(2.496)\end{array}$ & d.v. \\
\hline \multicolumn{4}{|l|}{$\begin{array}{l}\text { Residence (lives with } \\
\text { another person) }\end{array}$} \\
\hline Parents & $\begin{array}{l}0.330 \\
(0.470)\end{array}$ & $\begin{array}{c}0.225 \\
(0.417)\end{array}$ & d.v. \\
\hline Self & $\begin{array}{l}0.464 \\
(0.499)\end{array}$ & $\begin{array}{r}0.649 \\
(0.477)\end{array}$ & d.v. \\
\hline Dorm & $\begin{array}{l}0.046 \\
(0.209)\end{array}$ & $\begin{array}{c}0.030 \\
(0.170)\end{array}$ & d.v. \\
\hline $\begin{array}{l}\text { Highest Grade } \\
\text { Completed }\end{array}$ & $\begin{array}{l}12.322 \\
(2.406)\end{array}$ & $\begin{array}{l}12.504 \\
(2.066)\end{array}$ & d.v. \\
\hline Weight & $\begin{array}{l}167.162 \\
(29.014)\end{array}$ & $\begin{array}{l}133.100 \\
(25.846)\end{array}$ & Weight in pounds. 1982 variable \\
\hline Married & $\begin{array}{l}0.223 \\
(0.417)\end{array}$ & $\begin{array}{c}0.348 \\
(0.477)\end{array}$ & d.v. \\
\hline In Armed Services & $\begin{array}{l}0.019 \\
(0.137)\end{array}$ & $\begin{array}{c}0.005 \\
(0.071)\end{array}$ & d.v. \\
\hline \multicolumn{4}{|l|}{$\begin{array}{l}\text { Ethnic Background } \\
\text { (American) }\end{array}$} \\
\hline British & $\begin{array}{l}0.199 \\
(0.399)\end{array}$ & $\begin{array}{c}0.223 \\
(0.416)\end{array}$ & d.v. \\
\hline Indian & $\begin{array}{l}0.001 \\
(0.036)\end{array}$ & $\begin{array}{c}0.001 \\
(0.037)\end{array}$ & d.v. \\
\hline French & $\begin{array}{l}0.046 \\
(0.211)\end{array}$ & $\begin{array}{l}0.065 \\
(0.246)\end{array}$ & d.v. \\
\hline German & $\begin{array}{l}0.182 \\
(0.386)\end{array}$ & $\begin{array}{c}0.168 \\
(0.374)\end{array}$ & d.v. \\
\hline Irish & $\begin{array}{l}0.058 \\
(0.233)\end{array}$ & $\begin{array}{c}0.050 \\
(0.217)\end{array}$ & d.v. \\
\hline
\end{tabular}




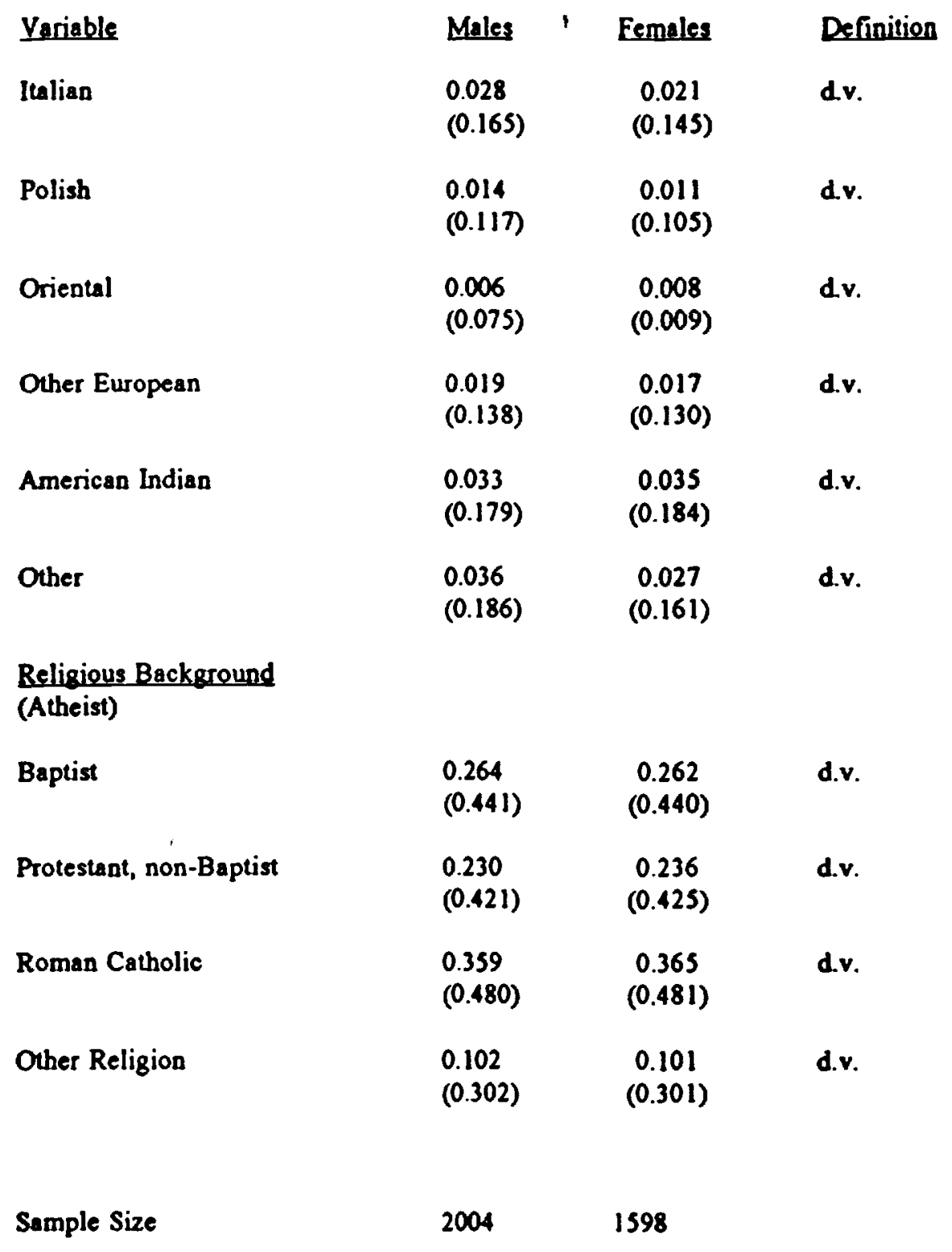


Table 2

Akohol Demand Equations, Short Form

Younger Cohort

Male Sample, NLSY, 1984

\begin{tabular}{|c|c|c|c|}
\hline Variable & In DPM $\mid D P M>0$ & $\operatorname{Pr}(\mathrm{DPM}>0)$ & Pr(Binge) \\
\hline Intercept & $\begin{array}{r}2.612^{\circ} \\
(0.224)\end{array}$ & $\begin{array}{r}1.020^{\circ} \\
(0.366)\end{array}$ & $\begin{array}{l}-2.114^{4} \\
(0.395)\end{array}$ \\
\hline Beer Tax & $\begin{array}{l}-0.149^{\circ} \\
(0.074)\end{array}$ & $\begin{array}{l}-0.140 \\
(0.112)\end{array}$ & $\begin{array}{l}-0.178 \\
(0.133)\end{array}$ \\
\hline Legal Drinking Status, & $\begin{array}{l}0.145 \\
(0.101)\end{array}$ & $\begin{array}{l}0.019 \\
(0.162)\end{array}$ & $\begin{array}{l}0.170 \\
(0.171)\end{array}$ \\
\hline $\begin{array}{l}\text { Father with } \\
\text { Drinking Problem }\end{array}$ & $\begin{array}{l}0.197 \\
(0.083)\end{array}$ & $\begin{array}{l}0.614^{\circ} \\
(0.159)\end{array}$ & $\begin{array}{l}0.3690 \\
(0.139)\end{array}$ \\
\hline Female & - & 一 & - \\
\hline Bleck & $\begin{array}{l}-0.196 \\
(0.139)\end{array}$ & $\begin{array}{l}-0.342 \\
(0.218)\end{array}$ & $\begin{array}{l}-0.250 \\
(0.246)\end{array}$ \\
\hline Hispanic & $\begin{array}{l}-0.068 \\
(0.128)\end{array}$ & $\begin{array}{l}-0.458 \\
(0.226)\end{array}$ & $\begin{array}{l}-0.012 \\
(0.220)\end{array}$ \\
\hline \multicolumn{4}{|l|}{$\begin{array}{l}\text { Parents' Education } \\
\text { (Ress than } 12 \text { years) }\end{array}$} \\
\hline \multicolumn{4}{|l|}{ Mother } \\
\hline 12.15 years & $\begin{array}{l}-0.010 \\
(0.080)\end{array}$ & $\begin{array}{r}0.223^{+} \\
(0.135)\end{array}$ & $\begin{array}{r}0.017 \\
(0.137)\end{array}$ \\
\hline $16+$ years & $\begin{array}{c}0.082 \\
(0.146)\end{array}$ & $\begin{array}{l}0.096 \\
(0.254)\end{array}$ & $\begin{array}{l}-0.009 \\
(0.247)\end{array}$ \\
\hline \multicolumn{4}{|l|}{ Father } \\
\hline 12.15 year & $\begin{array}{l}-0.048 \\
(0.078)\end{array}$ & $\begin{array}{r}0.319 \\
(0.133)\end{array}$ & $\begin{array}{l}-0.126 \\
(0.134)\end{array}$ \\
\hline $16+$ years & $\begin{array}{l}-0.126 \\
(0.118)\end{array}$ & $\begin{array}{c}0.291 \\
(0.212)\end{array}$ & $\begin{array}{l}-0.008 \\
(0.196)\end{array}$ \\
\hline Number of Sibling & $\begin{array}{c}0.010 \\
(0.014)\end{array}$ & $\begin{array}{l}-0.009 \\
(0.023)\end{array}$ & $\begin{array}{c}0.032 \\
(0.024)\end{array}$ \\
\hline Adjusted $R^{2}$ & 0.051 & - & - \\
\hline Extimation & OLS & Logi & Logit \\
\hline
\end{tabular}

Younger cohort includes those tumple members age 19-22, inclusive, in 1984. Cases with missine obeervations are exchuded Additional explanatory variables include age, religion, and ethnic backejoud dummy variables. The three cohmos of aumbers in each cable represente the estimaled coefricients and (aymptotic) standard errors for equations with the following dependent variables:

In DPM|DPM>0; In "drinks per month." The sample is limited to those who consumed a kast one drink

PR(DPM>0): the in-odde that the respondent consumed at leas one drink in the previous month

PR(Drunk): the ln-odds that the respoedenl consumed six of more drinks on a keat four cecasions in the previous month

Sentinically significant at the 0.01 confidence level, one-tuiled tea.

statistically significant at the 0.05 confidence level, one-tailed tent. 
Table 3

Alcohol Demand Equatlons, Long Form

Younger Cohort

Male Sample, NLSY, 1984

Variable

Intercept

Beer Tax

Legal Drinking Status,

Father with

Drinking Problem

Black

Hispanic

Parents' Education

(less than 12 years)

Mother

12-15 years

$16+$ years

Father

12-15 years

$16+$ years

Number of Siblings on $D P M \perp D P M>0$

1.660

(1.166)

$-0.192^{\circ}$

$(0.078)$

0.157

(0.105)

0.094

$(0.087)$

$-0.076$

(0.145)

$-0.004$

(0.132)
Pr(DPM $=0)$

0.471

(2.015)

$-0.161$

(0.120)

0.109

(0.174)

$0.553^{\circ}$

(0.169)

$-0.338$

$(0.238)$

$-0.397$

(0.245)
Proinge)

$-2.680$

(1.967)

$-0.255^{\circ}$

(0.146)

0.183

(0.182)

0.176

(0.150)

$-0.081$

(0.263)

0.221

(0.230)
0.017

$(0.084)$

0.093

(0.151)

0.011

(0.083)

0.008

$(0.127)$

$-0.007$

$(0.016)$
$-0.220$

$(0.146)$

0.086

(0.275)

$0.382^{\circ}$

(0.143)

0.346

(0.233)

$-0.042^{\circ}$

(0.025)
0.061

(0.145)

0.046

$(0.260)$

$-0.049$

(0.143)

0.182

$(0.213)$

$-0.007$

$(0.027)$

\section{Residence}

(lives with another person)

Parents,

Self,

Dorm,
$-0.066$

(0.102)

$0.205^{\circ}$

(0.109)

0.100

(0.152) $0.284^{\circ}$

(0.165)

$0.727^{\circ}$

(0.189)

$0.729^{\circ}$

(0.274)
0.118

(0.174)

0.254

(0.187)

0.424

(0.262) 


\begin{tabular}{|c|c|c|c|}
\hline Veriable & IDPMIDPM $>0$ & $\operatorname{Pr}(D P M>0)$ & Pr(Binge) \\
\hline $\begin{array}{l}\text { Highest Grade } \\
\text { Completed }\end{array}$ & $\begin{array}{l}-0.095^{\circ} \\
(0.022)\end{array}$ & $\begin{array}{l}-0.099^{\circ} \\
(0.038)\end{array}$ & $\begin{array}{l}-0.135^{\circ} \\
(0.037)\end{array}$ \\
\hline en(Weight) & $\begin{array}{r}0.434^{\circ} \\
(0.215)\end{array}$ & $\begin{array}{c}0.267 \\
(0.376)\end{array}$ & $\begin{array}{c}0.529 \\
(0.363)\end{array}$ \\
\hline Married, & $\begin{array}{l}-0.555^{\circ} \\
(0.136)\end{array}$ & $\begin{array}{l}-0.827^{\circ} \\
(0.229)\end{array}$ & $\begin{array}{l}-0.828^{\circ} \\
(0.249)\end{array}$ \\
\hline Number of Kids, & $\begin{array}{l}0.100 \\
(0.100)\end{array}$ & $\begin{array}{c}0.060 \\
(0.183)\end{array}$ & $\begin{array}{l}0.309 \\
(0.173)\end{array}$ \\
\hline \multicolumn{4}{|l|}{$\begin{array}{l}\text { Expected Number } \\
\text { of Kids (zero) }\end{array}$} \\
\hline $1-3$ & $\begin{array}{c}0.063 \\
(0.111)\end{array}$ & $\begin{array}{l}-0.060 \\
(0.194)\end{array}$ & $\begin{array}{l}-0.123 \\
(0.189)\end{array}$ \\
\hline 4 or more & $\begin{array}{l}0.218 \\
(0.148)\end{array}$ & $\begin{array}{l}-0.089 \\
(0.260)\end{array}$ & $\begin{array}{l}0.050 \\
(0.251)\end{array}$ \\
\hline In Armed Services & $\begin{array}{c}0.273 \\
(0.175)\end{array}$ & $\begin{array}{r}0.616^{\circ} \\
(0.366)\end{array}$ & $\begin{array}{l}0.075 \\
(0.312)\end{array}$ \\
\hline Adjusted $\mathbf{R}^{2}$ & 0.076 & - & - \\
\hline Estimation & OLS & Logit & Logit \\
\hline
\end{tabular}

Younger cohort includes those sample members age 19-22, inclusive, in 1984. Cases with missing observations are excluded. Additional explanstory variables include age, religion, and ethnic backgroud dummy variables. The three columns of numbers in each table represent the estimated coefricients and (asymplotic) standard errors for equations with the following dependent variables:

in DPM|DPM $>0$; to "drinks per month." The sample is limited to those who consumed at least one drink.

PR(DPM $>0)$ : the m-adds that the respondent consumed at least one drink in the previous month

PR(Drunk): the th-odds that the respondent consumed six or more drinks on at least four occasions in the previous month.

Statistically significant at the 0.01 confidence level, one-tailed lest.

"Statistically significant at the 0.05 confidence level, one-tailed test.

Statistically significant at the 0.01 confidence level, one-tailed test

Statistically significant at the 0.05 confidence level, one-tailed test 
Table 4

Alcohol Demand Equations, 1984

NLSY

Extract of Coefficient Estimates for Alcohol Control Variables

Short and Long Forms

\begin{tabular}{rccc} 
& \multicolumn{3}{c}{ Coefficients for mDPM $\mid D P M>0$} \\
& Men & Women & Combined \\
Young -Short & $-0.149^{\circ}$ & $-0.140^{\circ}$ & $-0.145^{\circ}$ \\
Long & $-0.192^{\circ}$ & -0.128 & $-0.156^{\circ}$ \\
Old - Short & $-0.140^{\circ}$ & $-0.221^{\circ}$ & $-0.177^{\circ}$ \\
Long & -0.071 & $-0.189^{\circ}$ & -0.120 \\
& & & \\
& & Legal Status & \\
& & Women & Combined \\
& & 0.090 & $0.125^{\circ}$ \\
Young -Short & 0.145 & 0.083 & $0.129^{\circ}$ \\
Long & 0.157 &
\end{tabular}

Coefficients for $P R(D P M>0)$ logits

Beer Tax

$\begin{array}{rccc} & \text { Men } & \text { Women } & \text { Combined } \\ \text { Young -Short } & -0.140 & -0.253^{\circ} & -0.195^{\circ} \\ \text { Long } & -0.161 & -0.330^{\circ} & -0.249^{\circ} \\ \text { Old - Short } & -0.151 & -0.319^{\circ} & -0.238^{\circ} \\ \text { Long } & -0.014 & -0.304^{\circ} & -0.250^{\circ} \\ & & \text { Legal Status } & \\ & \text { Men } & \text { Women } & \text { Combined } \\ & 0.019 & 0.070 & 0.040 \\ \text { Young-Short } & 0.109 & 0.075 & 0.094 \\ \text { Long } & & \end{array}$




$$
\text { Beer Tax }
$$

$\begin{array}{rccc} & \text { Men } & \text { Women } & \text { Combined } \\ \text { Young -Short } & -0.178 & -0.102 & -0.156 \\ \text { Long } & -0.255^{b} & -0.015 & -0.178 \\ \text { Old - Short } & -0.112 & -1.085^{\circ} & -0.388^{b} \\ \text { Long } & -0.319 & -0.955^{b} & \end{array}$

\section{Legal Status}

Men Women Combined

Young-Short

0.170

0.011

0.130

Long

0.183

$-0.016$

0.124

For description of short and long form equations, see Tables 2 and 3.

'Statistically significant at the 0.01 confidence level, one-tailed test.

'Statistically significant at the 0.05 confidence level, one-tailed test. 
Table $\mathbf{5}$

Reduced Form Habit Equations

Estimated Coefficients and Standard Errors

Combined Sample, OLS estimates

\begin{tabular}{|c|c|c|c|c|c|c|c|c|}
\hline & & & Jes & & & & ales & \\
\hline & & $\begin{array}{l}\text { M } \\
\text { bit) }\end{array}$ & & $\begin{array}{l}\text { DPM } \\
\text { LS) }\end{array}$ & & $\begin{array}{l}\text { PM } \\
\text { bit) }\end{array}$ & & $\begin{array}{l}\mathrm{PM} \\
\mathrm{LS})\end{array}$ \\
\hline & $\begin{array}{l}\text { Short } \\
\text { Form }\end{array}$ & $\begin{array}{l}\text { Long } \\
\text { Form }\end{array}$ & $\begin{array}{l}\text { Short } \\
\text { Form }\end{array}$ & $\begin{array}{l}\text { Long } \\
\text { Form }\end{array}$ & $\begin{array}{l}\text { Short } \\
\text { Form }\end{array}$ & $\begin{array}{l}\text { Long } \\
\text { Form }\end{array}$ & $\begin{array}{l}\text { Short } \\
\text { Form }\end{array}$ & $\begin{array}{l}\text { Long } \\
\text { Form } \\
\end{array}$ \\
\hline Legal & $\begin{array}{c}3.907^{b} \\
(2.250)\end{array}$ & $\begin{array}{c}4.567^{\circ} \\
(2.218)\end{array}$ & $\begin{array}{r}0.080^{c} \\
(0.060)\end{array}$ & $\begin{array}{c}0.091^{c} \\
(0.060)\end{array}$ & $\begin{array}{r}6.378^{\circ} \\
(1.392)\end{array}$ & $\begin{array}{r}2.722^{\circ} \\
(1.090)\end{array}$ & $\begin{array}{c}0.104^{\circ} \\
(0.062)\end{array}$ & $\begin{array}{r}0.093^{\circ} \\
(0.061)\end{array}$ \\
\hline Legal Age at & 40.782 & 0.584 & 0.012 & 0.006 & $2.798^{\circ}$ & $2.783^{\circ}$ & $0.115^{\circ}$ & 0.117 \\
\hline 18 & $(1.200)$ & $(1.182)$ & $(0.031)$ & $(0.030)$ & $(0.727)$ & $(0.713)$ & $(0.031)$ & $(0.030)$ \\
\hline 19 or 20 & $\begin{array}{l}-2.923 \\
(2.279)\end{array}$ & $\begin{array}{l}-2.329 \\
(2.248)\end{array}$ & $\begin{array}{l}-0.074 \\
(0.061)\end{array}$ & $\begin{array}{l}-0.043 \\
(0.060)\end{array}$ & $\begin{array}{r}2.340^{c} \\
(1.520)\end{array}$ & $\begin{array}{r}2.563^{\circ} \\
(1.488)\end{array}$ & $\begin{array}{c}0.074 \\
(0.067)\end{array}$ & $\begin{array}{c}0.109^{b} \\
(0.066)\end{array}$ \\
\hline Beer Tax & $\begin{array}{l}-1.427 \\
(1.178)\end{array}$ & $\begin{array}{l}-1.348 \\
(1.162)\end{array}$ & $\begin{array}{l}-0.061^{\circ} \\
(0.029)\end{array}$ & $\begin{array}{l}-0.056^{\circ} \\
(0.028)\end{array}$ & $\begin{array}{l}-2.450^{\circ} \\
(0.724)\end{array}$ & $\begin{array}{l}-1.873^{\prime} \\
(0.711)\end{array}$ & $\begin{array}{l}-0.106^{\circ} \\
(0.030)\end{array}$ & $\begin{array}{l}-0.084^{\circ} \\
(0.029)\end{array}$ \\
\hline $\begin{array}{l}\text { Adjusted } \\
\text { R-Squared }\end{array}$ & $\cdots$ & $\cdots$ & 0.875 & 0.879 & $\cdots$ & $\ldots$ & 0.806 & 0.818 \\
\hline Sample Size & 11372 & 11372 & 9252 & 9252 & 12524 & 12524 & 8605 & 8605 \\
\hline
\end{tabular}

For description of short and long form equations, see Table 2. A full set of age-year interaction dummies is included in all Table $\mathbf{S}$ regressions.

a Statistically significant at the 0.01 level, one-tailed test.

b Statistically significant at the 0.05 level, one-tailed test.

c Statistically significant at the 0.10 level, one-tailed test. 
Tabla:6

Reduced Form Participation

and Binge Drinking Equations

Combined Sample, Logit estimates

\begin{tabular}{llll}
\multicolumn{2}{c}{ Females } & \multicolumn{2}{c}{ Males } \\
Short & Long & Short & Long \\
Form & Form & Form & Form
\end{tabular}

Participation

Legal

0.095

$(0.083)$

0.105

(0.085)

0.071

(0.098)

0.086

(0.099)

Legal Age at 14

18

$0.081^{b}$

(0.044)

$0.066^{\circ}$
$(0.045)$

$-0.044$

$(0.057)$

$-0.042$

$(0.058)$

19 or 20

0.100

0.093

0.140

0.155
(0.108)

(0.106)

$-0.217^{\circ}$

(0.039)

$-0.141^{*}$

(0.038)
(0.042)

(0.122)

$(0.121)$

$-0.147^{\circ}$

(0.045)

Binge

\begin{tabular}{|c|c|c|c|c|}
\hline Legal & $\begin{array}{c}0.020 \\
(0.152)\end{array}$ & $\begin{array}{c}0.004 \\
(0.155)\end{array}$ & $\begin{array}{c}0.021 \\
(0.104)\end{array}$ & $\begin{array}{c}0.042 \\
(0.105)\end{array}$ \\
\hline $\begin{array}{l}\text { Legal Age at } \\
\qquad 18\end{array}$ & $\begin{array}{c}0.256^{\circ} \\
(0.088)\end{array}$ & $\begin{array}{c}0.268^{\circ} \\
(0.090)\end{array}$ & $\begin{array}{c}0.111^{b} \\
(0.058)\end{array}$ & $\begin{array}{r}0.102^{b} \\
(0.059)\end{array}$ \\
\hline 19 or 20 & $\begin{array}{c}0.042 \\
(0.088)\end{array}$ & $\begin{array}{c}0.076 \\
(0.198)\end{array}$ & $\begin{array}{c}0.031 \\
(0.115)\end{array}$ & $\begin{array}{c}0.021 \\
(0.117)\end{array}$ \\
\hline Beer Tax & $\begin{array}{l}-0.170^{b} \\
(0.087)\end{array}$ & $\begin{array}{l}-0.122^{c} \\
(0.087)\end{array}$ & $\begin{array}{l}-0.001 \\
(0.053)\end{array}$ & $\begin{array}{c}0.017 \\
(0.054)\end{array}$ \\
\hline
\end{tabular}

For description of short and long form equations, see Table 2. A full set of age-year interaction dummies is included in all Table 6 regressions.

- Statistically significant at the 0.01 level, one-tailed test.

- Statistically significant at the 0.05 level, one-tailed test.

- Statistically significant at the 0.10 level, one-tailed test. 


\section{Table 7}

Habit Formation and Rational Addiction Models

Tobit Estimates

Coefficients and Standard Errors

\begin{tabular}{lllllll}
\multicolumn{3}{c}{ Short Form } & \multicolumn{3}{c}{ Long Form } \\
OLS & \multicolumn{1}{l}{ HF } & RA & & HF & RA \\
2SLS & OLS & 2SLS & OLS & 2SLS & OLS & 2SLS
\end{tabular}

Eemales $(n=6262)$

Consumption

$\begin{array}{rrrrrrrr}0.508^{*} & 0.617^{*} & 0.350^{\circ} & 0.314 & 0.484^{\circ} & 0.436^{*} & 0.336^{\circ} & 0.283^{\circ} \\ (0.013) & (0.212) & (0.013) & (0.013) & (0.013) & (0.129) & (0.013) & (0.136)\end{array}$

Consumption

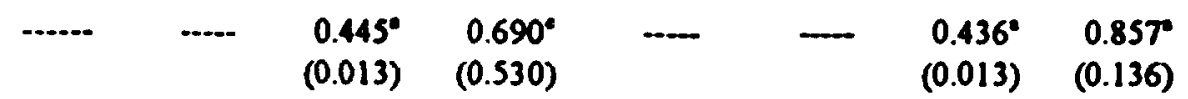

Beer Tax

$\begin{array}{llllllll}-1.547^{\circ} & -1.608^{\circ} & 0.833 & -0.067 & -1.178^{\circ} & -1.192^{\circ} & -0.596 & -0.333\end{array}$

$\begin{array}{llllllll}(0.790) & (0.901) & (0.716) & (1.017) & (0.985) & (0.888) & (0.768) & (0.888)\end{array}$

Legal Drinking

$\begin{array}{llllllll}3.980^{\circ} & 3.781^{\circ} & 3.410^{\circ} & 3.290^{\circ} & 3.958^{\circ} & 4.293^{\circ} & 3.398^{\circ} & 2.889^{\circ}\end{array}$

Status,

$\begin{array}{lllllllll}(1.450) & (1.829) & (1.316) & (1.969) & (1.439) & (1.681) & (1.372) & (1.718)\end{array}$

$F\left(\right.$ Partial $\left.R^{2}\right)$

$C_{\text {th }}$

$\begin{array}{cccccccc}\ldots \ldots & 8.21^{\circ} & \ldots & 6.17^{\circ} & \ldots & 9.79^{\circ} & \ldots & 9.84^{\circ} \\ \ldots & \ldots & \ldots & 2.81^{\circ} & \ldots & \ldots & \ldots & 10.30^{\circ} \\ \ldots & 0.27 & \ldots & 0.60 & \ldots & 0.52 & \ldots & 0.02\end{array}$

Hausman-Wu Test (p-value)

Males $(n=5686)$

Consumption

$\begin{array}{llllllll}0.450^{\circ} & 0.283 & 0.295^{\circ} & -0.102 & 0.436^{\circ} & 0.373^{\circ} & 0.290^{\circ} & 0.285^{\circ}\end{array}$

$\begin{array}{lllllllll}(0.011) & (0.484) & (0.010) & (0.468) & (0.011) & (0.182) & (0.011) & (0.156)\end{array}$

Consumption $_{n+1}$

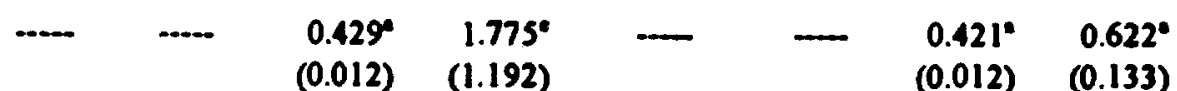

Beer Tax

$\begin{array}{llllllll}-1.811^{\circ} & -1.792 & -0.996 & 1.797 & -1.757^{\circ} & -1.763 & 0.989 & -0.224\end{array}$

$\begin{array}{llllllll}(1.236) & (1.430) & (1.106) & (2.789) & (1.230) & (1.403) & (1.115) & (1.252)\end{array}$

Legal Drinking

$\begin{array}{llllllll}0.318 & 1.264 & 0.887 & 1.127 & 0.515 & 0.946 & 0.269 & 1.840\end{array}$

$\begin{array}{llllllll}(2.257) & (3.622) & (1.794) & (2.953) & (2.244) & (2.735) & (2.034) & (2.294)\end{array}$

F(Partial R')

$C_{n !}$

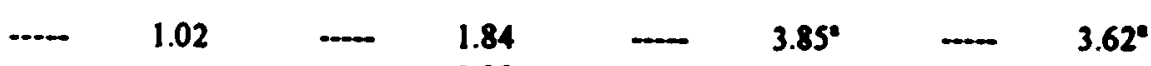

$C_{n+1}$

$\cdots \quad \cdots \quad \cdots \quad 0.88$

$-\quad 6.20^{\circ}$

Hausman-Wu Text

$\begin{array}{lllllllll}\cdots & 0.34 & \ldots & 0.30 & \ldots & \ldots & 0.38 & \ldots & 0.84\end{array}$

(p-value) 


\begin{tabular}{|c|c|c|c|c|c|c|c|c|}
\hline$: \cdot$ & & Shont & & & & & Form & \\
\hline & & $\mathbf{F}$ & $\mathbf{R}$ & & & IF & & $\boldsymbol{A}$ \\
\hline & OLS & 2 SLS & QLS & $2 S L S^{*}$ & QLS & 2SLS $\mathbf{S}^{\prime}$ & OLS & 2SLS \\
\hline Eull Sample $(N=119$ & & & & & & & & \\
\hline Consumption & $\begin{array}{r}0.464^{*} \\
(0.008)\end{array}$ & $\begin{array}{r}0.493^{\prime} \\
(0.250)\end{array}$ & $\begin{array}{r}0.308^{\circ} \\
(0.008)\end{array}$ & $\begin{array}{l}0.093 \\
(0.285)\end{array}$ & $\begin{array}{r}0.448 \\
(0.008)\end{array}$ & $\begin{array}{r}0.423^{\circ} \\
(0.119)\end{array}$ & $\begin{array}{l}0.301^{\circ} \\
(0.008)\end{array}$ & $\begin{array}{r}0.323^{\circ} \\
(0.119)\end{array}$ \\
\hline Consumption & $\cdots \cdot-$ & $\cdots$ & $\begin{array}{l}0.434^{\circ} \\
(0.009)\end{array}$ & $\begin{array}{l}1.135^{6} \\
(0.583)\end{array}$ & $\cdots$ & $\ldots$ & $\begin{array}{l}0.426^{\circ} \\
(0.009)\end{array}$ & $\begin{array}{r}0.807 \\
(0.111)\end{array}$ \\
\hline Beer $\operatorname{Tax}_{\mathrm{t}}$ & $\begin{array}{l}-1.715^{\circ} \\
(0.737)\end{array}$ & $\begin{array}{l}-1.786^{\circ} \\
(0.849)\end{array}$ & $\begin{array}{l}-0.925^{\circ} \\
(0.666)\end{array}$ & $\begin{array}{c}0.017 \\
(1.188)\end{array}$ & $\begin{array}{l}-1.431^{\circ} \\
(0.733)\end{array}$ & $\begin{array}{l}-1.461^{\circ} \\
(0.838)\end{array}$ & $\begin{array}{l}-0.742 \\
(0.665)\end{array}$ & $\begin{array}{l}-0.333 \\
(0.843)\end{array}$ \\
\hline $\begin{array}{l}\text { Legal Drinking } \\
\text { Status, }\end{array}$ & $\begin{array}{r}2.508^{\circ} \\
(1.347)\end{array}$ & $\begin{array}{l}2.564^{\circ} \\
(1.926)\end{array}$ & $\begin{array}{r}2.112^{6} \\
(1.218)\end{array}$ & $\begin{array}{r}2.565^{\circ} \\
(1.982)\end{array}$ & $\begin{array}{l}2.558^{6} \\
(1.338)\end{array}$ & $\begin{array}{r}2.865^{\circ} \\
(1.612)\end{array}$ & $\begin{array}{r}2.146^{\circ} \\
(1.214)\end{array}$ & $\begin{array}{r}2.216^{\circ} \\
(1.587)\end{array}$ \\
\hline $\begin{array}{l}\text { F(Partial R') } \\
C_{k-1} \\
C_{k+1}\end{array}$ & $\cdots$ & $\begin{array}{c}4.45^{\circ} \\
-\cdots-\cdots\end{array}$ & $\ldots$ & $\begin{array}{r}4.79^{\prime} \\
27.18^{4}\end{array}$ & $\cdots$ & $\begin{array}{c}8.81^{\circ} \\
\ldots\end{array}$ & $\ldots$ & $\begin{array}{r}9.64^{\circ} \\
12.97^{\circ}\end{array}$ \\
\hline $\begin{array}{l}\text { Hausman-Wu Test } \\
\text { (p-value) }\end{array}$ & $\cdots$ & 0.99 & $\cdots$ & 0.14 & $\cdots$ & 0.61 & $m$ & 0.05 \\
\hline
\end{tabular}

For description of short and long form equations, see table 2. Year dummies interacted with age dummies in all Table 7 regressions.

- Statistically significant at the 0.01 level, one-tailed test.

b Statistically significant at the 0.05 level, one-tailed test.

c Statistically significant at the 0.10 level, one-tailed test.

d Excluded instrumental variables include one-period lags of beer tax and legal status, and purchase age at age 14 dummies

- Excluded instrumental variables include those in footnote (d), plus one-period leads of beer tax and legal status.

f Excluded instrumental variables include those in footnote (d), plus one-period lags of long-form variables.

8 Excluded instrumental variables include those in footnote (d). plus one-period leads and lags of long-form variables. 